\title{
Enrichment of trace elements in the clay size fraction
} of mining soils

\author{
Patrícia Gomes • Teresa Valente • M. Amália Sequeira Braga • \\ J. A. Grande • M. L. de la Torre
}

Received: 12 January 2015 / Accepted: 13 February 2015

(C) Springer-Verlag Berlin Heidelberg 2015

\begin{abstract}
Reactive waste dumps with sulfide minerals promote acid mine drainage (AMD), which results in water and soil contamination by metals and metalloids. In these systems, contamination is regulated by many factors, such as mineralogical composition of soil and the presence of sorption sites on specific mineral phases. So, the present study dedicates itself to understanding the distribution of trace elements in different size fractions $(<2-\mathrm{mm}$ and $<2-\mu \mathrm{m}$ fractions) of mining soils and to evaluate the relationship between chemical and mineralogical composition. Cerdeirinha and Penedono, located in Portugal, were the waste dumps under study. The results revealed that the two waste dumps have high degree of contamination by metals and arsenic and that these elements are concentrated in the clay size fraction. Hence, the higher degree of contamination by toxic elements, especially arsenic in Penedono as well as the role of clay minerals, jarosite, and goethite in retaining trace elements has management implications. Such information must be carefully thought in the rehabilitation projects to be planned for both waste dumps.
\end{abstract}

Keywords Mining soils · Contamination · Clay size fraction · Accumulation factor · Trace elements · Portugal

Responsible editor: Zhihong Xu

P. Gomes $\cdot$ T. Valente $(\bowtie) \cdot$ M. A. S. Braga

Centro de Investigação Geológica, Ordenamento e Valorização de

Recursos (CIG-R), Universidade do Minho, Campus de Gualtar,

4710-057 Braga, Portugal

e-mail: teresav@dct.uminho.pt

P. Gomes · T. Valente $\cdot$ J. A. Grande $\cdot$ M. L. de la Torre CIPIMS, Universidad de Huelva, Campus de la Rábida, Huelva, Spain

\section{Introduction}

Mining activity produces a large amount of not availed material that must be stored in appropriate conditions of stability, security, and integration with the surrounding landscape (Gomes 2011). These sterile materials, or mining wastes, are generated at various stages of the production process. If they are reactive, they will pose more environmental concern, due to their participation in contaminant mineral-water interactions processes. So, abandoned mining lands represent one of the most outstanding environmental risks, such as soil pollution by potentially toxic metals and metalloids. These problems affect many countries with historic mining activity (Thornton 1996; Fernández-Caliani et al. 2008), including Portugal. Across the country, about 200 abandoned mines were identified (Santos Oliveira et al. 2002), which constitute the national mining liability, whose abandonment occurred in an uncontrolled manner. In some of these mines, especially those which represented a great mobilization of sulfides, there is still a depreciation of environmental quality motivated by the reactive waste dumps (Valente 2004; Valente et al. 2011, 2012). In the weathering process of sulfides, oxidation generates acid mine drainage (AMD) mobilizing high amounts of acidity, sulfates, metals, and metalloids (Valente et al. 2009; Gomes 2011; Sarmiento et al. 2012; Valente et al. 2012), from which results water and soil contamination. Also, the pollutants may be transferred from these sites to nearby soils and water by wind-blown dispersion of fine particles. These events are responsible for the impact of mining and ore treatment on the ecosystem, even at long distances.

The behavior of trace elements in AMD-affected systems is regulated by many factors. First, element distribution into different particle sizes depends of the presence of sorption sites and of the mineralogical composition of soil (e.g., Acosta et al.
35 
2011). Fine particles, which include clay fraction, have high specific area that retains high amounts of metals. In addition, small particles are often soluble (Martínez-Martínez et al. 2010). Moreover, mobilization or fixation of elements in the soil can be regulated by the interactions between several biogeochemical processes, such as formation of secondary minerals (Kabata-Pendias and Pendias 1984; Cox et al. 1995; Malpas et al. 2001). Besides, the Fe-rich materials that compose the typical ochre-precipitates may adsorb or coprecipitate the toxic elements carried by AMD solutions (Valente et al. 2014). Therefore, to know the trace element distribution in fine soil particles is an important step for risk assessments of mining soils (Hardy and Cornu 2006; Acosta et al. 2009; Luo et al. 2011).

So, the main purpose of the present study comes in line with this environmental concern. It deals with the subject of trace elements distribution in two distinctive sulfide waste dumps, abandoned after decades of $\mathrm{W}$ and $\mathrm{Au}$ exploitation, respectively, Cerdeirinha and Penedono (Portugal). These two sites (Fig. 1) were not yet the subject of technical intervention for their environmental rehabilitation. The specific objectives of the present study are to evaluate the degree of contamination by trace elements and to analyze the role of the clay size fraction in the retention of contaminants.

\section{Material and methods}

92

Sites description

93

The two selected sites are located in regions with strong mining tradition for metals and so with a long historic in water and soil contamination by AMD (Valente and Leal Gomes 2009; Valente et al. 2012).

Cerdeirinha (Fig. 1) was exploited for W, in a skarn deposit with sulfides, mainly iron sulfides. The waste dumps have been formed by successive accumulation of sterile material from the treatment of tungsten ores. Penedono (Fig. 1), in a granitic context, was exploited, mainly for $\mathrm{Au}$, in quartz veins with sulfides. It was an important mining center for gold and other elements, such as arsenic, and the waste dumps are composed by sterile materials resulted from milling, hydrogravitic, and flotation operations.

Cerdeirinha has a more diverse mineral association, due to the skarn nature of the ore deposit. Here, phyrrhotite and pyrite are the most abundant sulfides, while at Penedono, there is arsenopyrite with minor pyrite. A main difference between the two ore deposits relies on the absence of carbonates and calcium silicates in Penedono, which act as neutralizing minerals in Cerdeirinha. A more complete paragenetic description of the two ore deposits can be found in Valente et al. (2012).
94 95 96 97 98 99 100 101 102 103 104 105 106 107 108 109 110 111 112 113
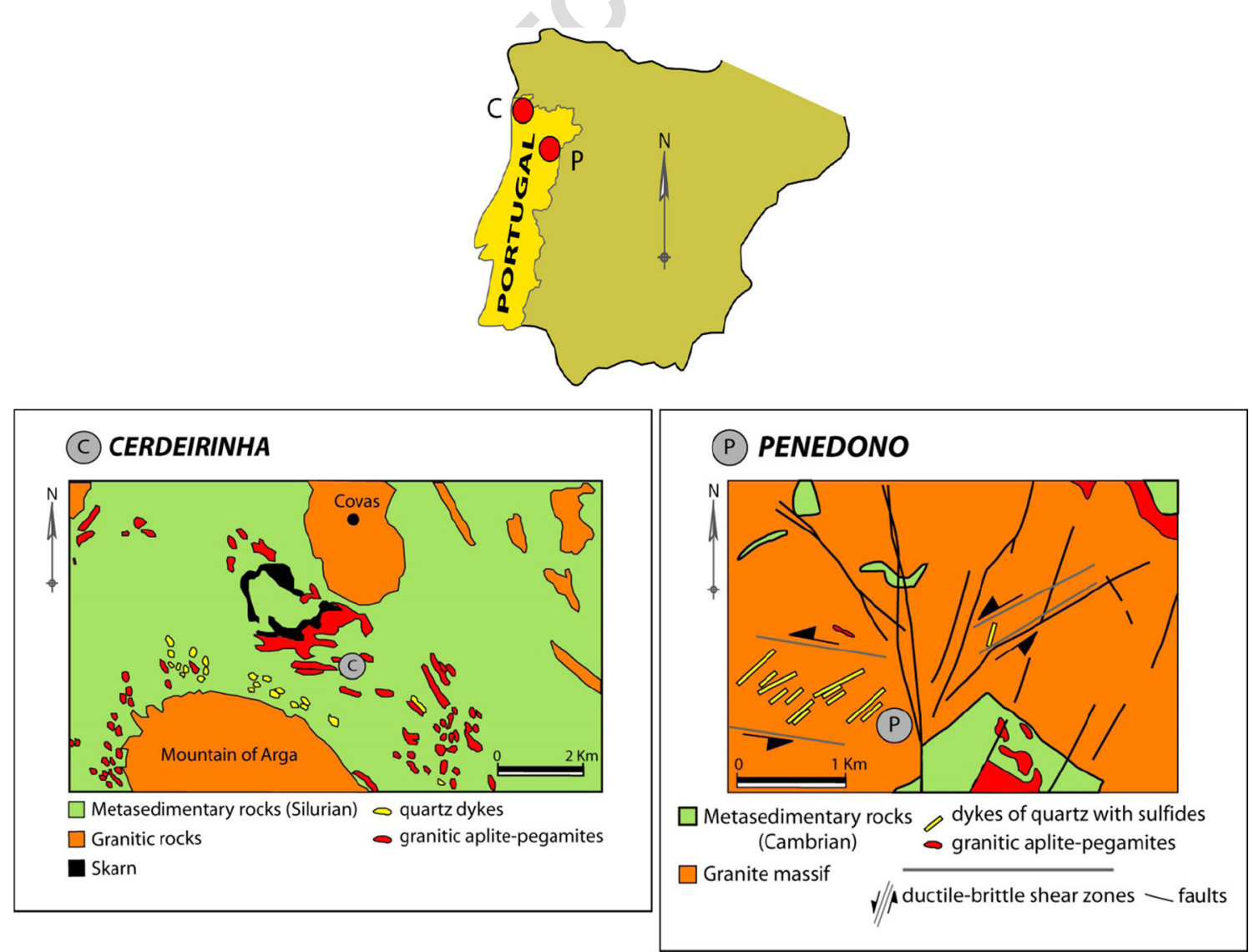

Fig. 1 Localization of two study sites 
Environ Sci Pollut Res

115 Sampling and analytical methods

116

117

118

119

120

121

122

123

124

125

126

127

128

129

130

131

132

133

134

135

136

137

138 vegetation cover. 2011). gy properties. were used.

\section{Results and discussion}

The methodology includes sampling and preparation procedures followed by a general characterization of the mining soils, regarding texture, general properties, mineralogy, and chemistry in two grain size fractions: $<2 \mathrm{~mm}$ (named bulk sample) and the clay size fraction $(<2 \mu \mathrm{m})$.

In the field, the samples represent the first $20 \mathrm{~cm}$ of substrate on which plants grow on the waste dumps. At each mine, the sampling sites represent the spatial variability, controlled by different aspects, including by the differences in the

Analytical procedures followed classical methodological approaches for texture and general soil properties (Gomes

Mineralogy was analyzed by X-ray diffraction (XRD) applied to both fractions. XRD was performed with a Philips $\mathrm{X}$ 'pert Pro-MPD diffractometer, using $\mathrm{Cu}-\mathrm{K} \alpha$ radiation, operated with a 2 theta step size of $0.02^{\circ}$ and a counting time of $1.25 \mathrm{~s}$. For the identification of clay minerals, the $<2-\mu \mathrm{m}$ fraction was separated by sedimentation and analyzed in oriented aggregates of air-dried, ethylene gycol-treated, and thermal-treated samples. The relative abundance of the mineral phases in both fractions was estimated by measuring the intensity of diagnostic diffraction peaks (Valente et al. 2012). For the study of compositional and morphological aspects, scanning electron microscopy (on gold coated samples) was used, with a LEICA S360 microscope combined with an energy dispersive system (SEM-EDS). Also, transmission electron microscopy was applied to provide compositional spectra, mineral identification by microdiffraction and morpholo-

The chemical composition ( $\mathrm{Fe}, \mathrm{Al}, \mathrm{Mn}, \mathrm{Cu}, \mathrm{Ni}, \mathrm{Pb}, \mathrm{Zn}, \mathrm{As}$, $\mathrm{Ba}, \mathrm{Bi}, \mathrm{Cr}, \mathrm{Sr}$, and $\mathrm{W}$ ) of both size fractions was analyzed by inductively coupled plasma/mass spectrometry (ICP/MS) at Activation Laboratory, Ltd. (Actlabs, Canada). For that, samples were pulverized in an Agata mortar and submitted to aqua regia digestion. Duplicate samples and check precision blanks as well as certified standards (GXR series) for accuracy

The two studied sites have acidic soils $(\mathrm{pH}<4)$, with low contents of nutrients. They differ in the contents of organic matter, presenting Cerdeirinha higher concentration (5\%) compared with Penedono, whose samples do not surpass the $1 \%$. Both soils can be considered as coarse soils, being classified as sandy loam, in accordance with the USDA texture classification system. So, the general properties are relatively similar in the two waste dumps. A detailed characterization of the mining soils can be found in Valente et al. (2012).
Mineralogy

164

The mineralogy of the mining soils is presented in Table 1 . According to XRD study, the most common minerals in bulk soil $(<2-\mathrm{mm}$ fraction) are quartz, $\mathrm{k}$-feldspar, plagioclase, and mica. In a general way, marcasite, pyrrhothite, pyrite, and jarosite are prominent minerals at Cerdeirinha. In contrast, Penedono shows clearly lower variability in this fraction, with quartz and feldspar as dominant phases. This result reflects the differences in the two ore paragenesis. In fact, at Cerdeirinha, the skarn nature of the ore deposit in association with massive sulfides contributes to higher mineralogical diversity (Gomes 2011), with minerals such as wollastonite and apatite. Table 2 reveals the differences in $<2-\mu \mathrm{m}$ fraction in the two waste dumps. The clay size fraction is also more diverse at Cerdeirinha. Here, the iron-rich minerals jarosite and goethite are the most abundant phases, followed by a set of clay minerals, including kaolinite and 2:1 clay minerals. On the other hand, at Penedono, kaolinite dominates, followed by jarosite and clay minerals, while goethite is vestigial.

Geochemistry

Metal concentrations in different size fraction

Chemical composition of the soil is shown in Fig. 2, where concentrations are compared in the two size fractions: $<2 \mathrm{~mm}$ and $<2 \mu \mathrm{m}$. It is possible to assess that elements such as Fe, $\mathrm{Al}$, and $\mathrm{As}$ are present in high quantities in the two waste dumps (i.e., in a range between $1537.5 \mathrm{mg} / \mathrm{kg}$ for $\mathrm{Al}$ in the $<2$-mm fraction at Penedono and 1,765,000 $\mathrm{mg} / \mathrm{kg}$ for $\mathrm{Fe}$ in the $<2-\mu \mathrm{m}$ fraction at Cerdeirinha). Despite this fact, $\mathrm{Fe}$ was the most abundant element in soil of the two waste dumps and As has higher values at Penedono (with $25,875 \mathrm{mg} / \mathrm{kg}$ in the $<2-\mu \mathrm{m}$ fraction). Results suggest that the ore deposits have influence in the concentrations of trace elements in the soil. Cerdeirinha is dominated by iron sulfides, thus increasing the concentration of Fe. The element As is present at Penedono in higher amount, due to dissolution of arsenopyrite, which is the main sulfide phase present in the ore deposit.

Furthermore, Ni, Ba, Cr, and $\mathrm{Sr}$ appear in low concentrations at both sites. As opposed to Cerdeirinha, Penedono has lower concentrations of $\mathrm{Mn}, \mathrm{Cu}, \mathrm{Zn}$, and $\mathrm{Bi}$, showing a less mineralogical and metal diversity (Table 1), also because soils enriched in quartz tend to have lower levels of trace elements (Silva et al. 2013). On the other hand, Penedono has higher concentration of $\mathrm{Pb}$. Moreover, in this site, all elements are concentrated in $<2-\mu \mathrm{m}$ fraction, without exception. In contrast, some elements such $\mathrm{Mn}$ and $\mathrm{W}$ are in larger amount in the bulk soil fraction of Cerdeirinha. These exceptions can be explained by the presence of wolframite crystals as a consequence of low recuperation rates in the ore treatment.
184

165

166

167

168

169

170

171

172

173

174

175

176

177

178

179

180

181

182

185 186 187 188 189 190 191 192 193 194 195 196 197 198 199 
t1.1 Table 1 Mineralogical assemblage of the two size fractions: $<2-\mu \mathrm{m}$ fraction (clay minerals and associated minerals) and $<2$-mm fraction (bulk soil)

t1.2 Size fraction

t1.3<2 $<\mathrm{m}$

$\mathrm{t} 1.4<2 \mathrm{~mm}$

$$
\begin{aligned}
& \text { Cerdeirinha }(n=6) \\
& \mathrm{Jt}>>\mathrm{Il}>\mathrm{Go}>\mathrm{S}>\mathrm{Gb}>\mathrm{M}-\mathrm{V}>\mathrm{Cl}>\mathrm{K} \\
& \mathrm{Q}>>\mathrm{P}>\mathrm{F}>\mathrm{Mi}>\mathrm{Mar}>\mathrm{Pry}=\mathrm{MgS}> \\
& \mathrm{Py}=\mathrm{Go}=\mathrm{Jt}=\mathrm{Ap}>\mathrm{Cm}=\mathrm{Am}=\mathrm{Wo}>\mathrm{To}
\end{aligned}
$$

Penedono $(n=8)$

$\mathrm{K}>\mathrm{Jt}>\mathrm{Il}>\mathrm{S}>$ Go

$\mathrm{Q}>>>\mathrm{F}>\mathrm{Mi}>\mathrm{P}>\mathrm{Cm}=\mathrm{Jt}$

$J t$ jarosite, $I l$ illite, $G o$ goethite, $G b$ gibbsite, $M L$ mixed-layered mica-vermiculite, $S$ smectite, $C l$ chlorite, $K$ kaolinite, $Q$ quartz, $F$ k-feldspar, $P$ plagioclase, $\mathrm{Mi}$ mica, $\mathrm{Cm}$ clay minerals, $P y$ pyrite, Mar marcasite, $P y r$ pyrrhotite, $M g s$ magnesite, $A p$ apatite, Am amphibole, $W o$ wollastonite, $T o$ Tourmaline

t2.1 Table 2 Mineralogical composition of the mining waste dump soils estimated by XRD in the $<2-\mu \mathrm{m}$ fraction (clay minerals and associated minerals)

Although not detected in XRD study, such a presence was confirmed by SEM study.

Therefore, the results obtained for soil chemistry reflect the original differences in the ore paragenesis as already noted in the mineralogy. Cerdeirinha has the highest concentrations of $\mathrm{Fe}$, reaching $15 \%$, which is in accordance with the abundance of iron sulfides. On the other hand, the highest contamination by As occurs at Penedono, with contents up to $3 \%$.

These results also show that both sites have a similar trend in what concerns the relation between the two size fractions. In fact, the highest concentrations are observed in the clay size fraction for most of the elements, with the exception of manganese and tungsten in the Cerdeirinha samples.

\section{Correlation between trace elements}

Correlation analysis provides an effective way to reveal the relationships between trace elements in soil. Tables 3 and 4 show the correlation matrixes for Cerdeirinha and Penedono, respectively, considering the concentrations obtained in the $<2$ - $\mu \mathrm{m}$ fraction.

Strong correlations occur between concentrations of some trace elements in this fine fraction. However, the elements behave somewhat differently at both sites. At Cerdeirinha (Table 3), Fe is significant and positively correlated with $\mathrm{Bi}$ (0.890). Al is correlated with $\mathrm{Ba}(0.819)$; Mn had close relationships with $\mathrm{Zn}(0.815)$ and $\mathrm{As}(0.823)$. $\mathrm{Cu}$ and $\mathrm{Ni}$ are related with $\mathrm{Cr}$. These high correlations indicate that these elements associate in the parent materials and suggest similar

\begin{tabular}{|c|c|c|c|c|c|c|c|c|c|}
\hline & & $\mathrm{C}$ & Il & $M-V$ & $\mathrm{Sm}$ & K & Go & $\mathrm{Jt}$ & Gi \\
\hline Cerdeirinha & Average & 5 & 10 & 6 & 8 & 4 & 9 & 51 & 7 \\
\hline Penedono & & - & 19 & - & 13 & 40 & 1 & 27 & - \\
\hline
\end{tabular}
geochemical behavior during weathering process, as observed

Waste dumps $<2-\mu \mathrm{m}$ fraction $(\%)$

$C$ chlorite, $I l$ illite, $M-V$ mixed-layer mica-vermiculite, $S m$ smectite, $K$ kaolin mineral, Go goethite, $J t$ jarosite, Gi gibbsite for Bi. Bismuth occurs at the ore deposit of Cerdeirinha as native bismuth and bismuthinite (Valente et al 2012). However, in this Fe-rich paragenesis, dissolution of bismuth followed by precipitation of iron-rich minerals may take place. Convolute bands of iron oxyhydroxides (probably goethite) with $\mathrm{Bi}$ inside iron-rich crusts were observed by SEM. In fact, previous studies revealed the tendency of $\mathrm{Bi}$ to co-precipitate with hydrous Fe oxides (Augustithis 1995), hence justifying the observed correlation between $\mathrm{Fe}$ and $\mathrm{Bi}$.

Close correlation between $\mathrm{Cu}, \mathrm{Cr}$, and $\mathrm{Ni}$ indicates the sulfides, such as pyrite, chalcopyrite, sphalerite, gersdorfite, and other complex sulfides from the ore paragenesis (Valente et al. 2012) as the main common source of these elements. The same happens for Mn with As and $\mathrm{Zn}$, reflecting the association between ore minerals and sulfides. Identically, in geochemical processes, $\mathrm{Ba}$ is commonly associated with $\mathrm{K}$, in alkaline feldspars and biotite. So, the high correlation $(0.819)$ of the pair Ba-Al is reflecting this lithophilic affinity.

At Penedono, the correlation matrix (Table 4) indicates that $\mathrm{Al}$ is effectively correlated with $\mathrm{Mn}(0.939)$ and $\mathrm{Sr}(0.782)$ while $\mathrm{Mn}$ appears correlated with $\mathrm{Ba}(0.765)$ and $\mathrm{Pb}$ is related

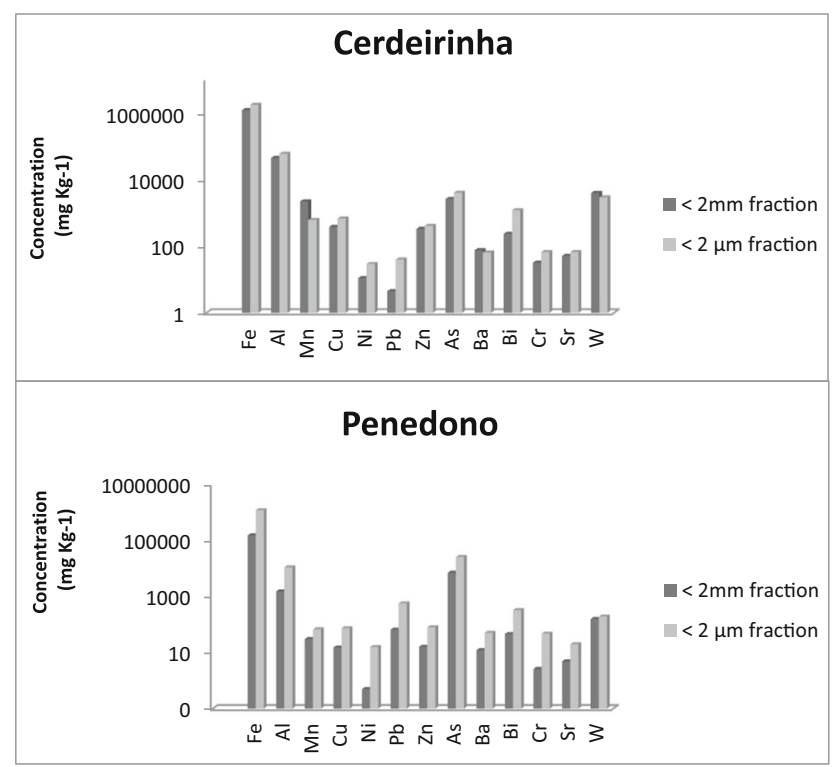

Fig. 2 Concentration and distribution of metals in different particle size fractions 
Environ Sci Pollut Res

Q4 t3.1 Table 3 Correlation matrix of trace elements concentration in Cerdeirinha $(<2-\mu \mathrm{m}$ fraction $)$

\begin{tabular}{|c|c|c|c|c|c|c|c|c|c|c|c|c|c|}
\hline $\mathrm{t} 3.2$ & & $\mathrm{Fe}$ & $\mathrm{Al}$ & $\mathrm{Mn}$ & $\mathrm{Cu}$ & $\mathrm{Ni}$ & $\mathrm{Pb}$ & $\mathrm{Zn}$ & As & $\mathrm{Ba}$ & $\mathrm{Bi}$ & $\mathrm{Cr}$ & $\mathrm{Sr}$ \\
\hline $\mathrm{t} 3.3$ & $\mathrm{Fe}$ & 1.000 & & & & & & & & & & & \\
\hline $\mathrm{t} 3.4$ & $\mathrm{Al}$ & -0.722 & 1.000 & & & & & & & & & & \\
\hline $\mathrm{t} 3.5$ & $\mathrm{Mn}$ & 0.306 & 0.112 & 1.000 & & & & & & & & & \\
\hline t 3.6 & $\mathrm{Cu}$ & -0.785 & 0.253 & -0.359 & 1.000 & & & & & & & & \\
\hline t 3.7 & $\mathrm{Ni}$ & -0.176 & -0.377 & -0.283 & 0.512 & 1.000 & & & & & & & \\
\hline $\mathrm{t} 3.8$ & $\mathrm{~Pb}$ & 0.131 & -0.672 & 0.014 & 0.439 & 0.721 & 1.000 & & & & & & \\
\hline t 3.9 & $\mathrm{Zn}$ & 0.146 & 0.120 & 0.815 & -0.378 & -0.037 & -0.029 & 1.000 & & & & & \\
\hline $\mathrm{t} 3.10$ & As & 0.452 & -0.206 & 0.823 & -0.300 & -0.391 & 0.240 & 0.507 & 1.000 & & & & \\
\hline $\mathrm{t} 3.11$ & $\mathrm{Ba}$ & -0.375 & 0.819 & 0.341 & -0.039 & -0.195 & -0.621 & 0.355 & -0.180 & 1.000 & & & \\
\hline $\mathrm{t} 3.12$ & $\mathrm{Bi}$ & 0.890 & -0.826 & 0.208 & -0.464 & -0.100 & 0.422 & -0.089 & 0.560 & -0.646 & 1.000 & & \\
\hline $\mathrm{t} 3.13$ & $\mathrm{Cr}$ & -0.548 & -0.098 & -0.495 & 0.921 & 0.745 & 0.653 & -0.472 & -0.386 & -0.268 & -0.232 & 1.000 & \\
\hline $\mathrm{t} 3.14$ & $\mathrm{Sr}$ & 0.767 & -0.820 & -0.310 & -0.472 & 0.254 & 0.249 & -0.290 & -0.164 & -0.503 & 0.687 & -0.103 & 1.000 \\
\hline
\end{tabular}

261 with $\mathrm{Bi}$ (0.783). In turn, the clear association between $\mathrm{Ni}$ and $262 \mathrm{Zn}(0.809)$ and $\mathrm{Ni}$ and $\mathrm{Cr}$ (0.976) stands out, which reveals a 263 common origin for all, possibly represented by the sulfides. At 264 this site, $\mathrm{Bi}$ correlates more strongly with $\mathrm{Pb}$, which may also 265 be reflecting its chalcophile affinity, which results in its 266 partitioning into sulfides, especially galena. In fact, $\mathrm{Bi}$ is com267 mon in late $\mathrm{Pb}-\mathrm{Zn}$ veins or perigranitic hydrothermal vein 268 deposits as that of Penedono. The strong correlations among $269 \mathrm{Mn}, \mathrm{Al}, \mathrm{Sr}$, and Ba may reveal the lithophilic affinity of these 270 elements and their link with plagioclase and micas, highly 271 abundant in the clay size fraction as demonstrated by the 272 XRD study.

\section{Accumulation factor}

274 The enrichment in the clay size fraction with respect to the 275 bulk soil can be expressed through the determination of an 276 accumulation factor, which reflects the ratio between contents 277 in both fractions.
Figure 3 represents the accumulation factor $\left(\mathrm{AF}_{x}\right)$ for a set of elements that pose greater environmental concern, calculated by using Eq. (1) (Acosta et al. 2009).

$\mathrm{AF}_{x}=X_{\text {fraction }} / X_{\text {bulk }}$

As can be seen in Fig. 3, the accumulation factor (AF) for Cerdeirinha showed consistent values $\sim 1.0$ for $\mathrm{Cu}, \mathrm{Zn}$, and As. Here, $\mathrm{Ni}$ and $\mathrm{Bi}$ and specially $\mathrm{Pb}$ showed higher enrichment trends $(\mathrm{AF}=14)$. At Penedono, the $\mathrm{AF}$ is generally higher than at Cerdeirinha. Ni stands out with an AF around 28.

In a general way, the concentrations (Fig. 2) and AFs (Fig. 3) of trace elements in the two fractions demonstrated an enrichment of the finer fraction. Preliminary works reported that the preferential partitioning of trace metals is in the clay fraction (Moore et al. 1989; Fernández-Caliani et al.
278

279 280

t4.1 Table 4 Correlation matrix (Person coefficients) of trace elements concentration in Penedono $(<2-\mu \mathrm{m}$ fraction)

\begin{tabular}{|c|c|c|c|c|c|c|c|c|c|c|c|c|c|}
\hline $\mathrm{t} 4.2$ & & $\mathrm{Fe}$ & $\mathrm{Al}$ & $\mathrm{Mn}$ & $\mathrm{Cu}$ & $\mathrm{Ni}$ & $\mathrm{Pb}$ & $\mathrm{Zn}$ & As & $\mathrm{Ba}$ & $\mathrm{Bi}$ & $\mathrm{Cr}$ & $\mathrm{Sr}$ \\
\hline $\mathrm{t} 4.3$ & $\mathrm{Fe}$ & 1.000 & & & & & & & & & & & \\
\hline $\mathrm{t} 4.4$ & $\mathrm{Al}$ & -0.457 & 1.000 & & & & & & & & & & \\
\hline $\mathrm{t} 4.5$ & $\mathrm{Mn}$ & -0.240 & 0.939 & 1.000 & & & & & & & & & \\
\hline $\mathrm{t} 4.6$ & $\mathrm{Cu}$ & -0.375 & 0.308 & 0.325 & 1.000 & & & & & & & & \\
\hline $\mathrm{t} 4.7$ & $\mathrm{Ni}$ & 0.552 & -0.170 & -0.024 & -0.187 & 1.000 & & & & & & & \\
\hline $\mathrm{t} 4.9$ & $\mathrm{Zn}$ & 0.418 & 0.264 & 0.360 & -0.333 & 0.809 & -0.709 & 1.000 & & & & & \\
\hline $\mathrm{t} 4.10$ & As & 0.102 & 0.583 & 0.556 & -0.490 & -0.084 & -0.591 & 0.397 & 1.000 & & & & \\
\hline $\mathrm{t} 4.11$ & $\mathrm{Ba}$ & 0.349 & 0.584 & 0.765 & 0.129 & 0.508 & -0.547 & 0.682 & 0.435 & 1.000 & & & \\
\hline $\mathrm{t} 4.12$ & $\mathrm{Bi}$ & -0.376 & -0.423 & -0.533 & 0.123 & -0.334 & 0.783 & -0.673 & -0.624 & -0.578 & 1.000 & & \\
\hline $\mathrm{t} 4.13$ & $\mathrm{Cr}$ & 0.598 & -0.307 & -0.122 & -0.116 & 0.976 & -0.360 & 0.713 & -0.245 & 0.431 & -0.271 & 1.000 & \\
\hline
\end{tabular}




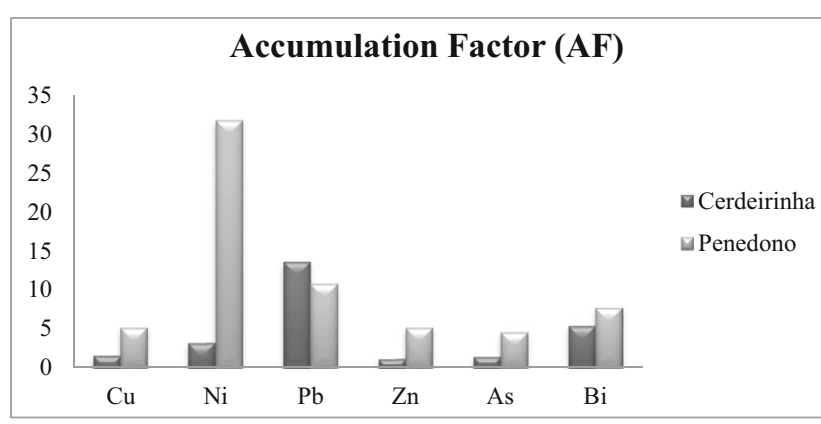

Fig. 3 Average values for accumulation factor in two waste dumps

2008; Luo et al. 2011). These might be attributed to greater surface area per unit of mass of the fine particles, which increase the adsorption capacity of this fraction (Wong et al 2006). Furthermore, finer soil particles have greater content of secondary minerals (clay minerals, Fe, Mn, and Al oxides and hydroxides and hydroxysulfates). In addition, metal enrichment in clay fraction was especially noticeable for $\mathrm{Ni}, \mathrm{Bi}$, and $\mathrm{Pb}$ at both waste dumps. Sposito (1989) suggested that duo to isomorphous substitution of $\mathrm{Ni}$ for $\mathrm{Fe}$ or $\mathrm{Mg}$ in the octahedral sheet of illite, Ni tends to accumulate in the finest fractions. This may be an explanation for having a higher amount of these elements in the $<2-\mu \mathrm{m}$ fraction, especially in Penedono, where there is a significant quantity of illite. Also, Kohut and Warren (2002) indicated that Ni may occur in Mg-bearing minerals such as smectite. Moreover, chlorite is normally composed by $\mathrm{Mg}, \mathrm{Al}$, and $\mathrm{Fe}$ and can also contain elements, such as $\mathrm{Cr}, \mathrm{Ni}$, and $\mathrm{Cu}$, according to the same author. This can justify the higher contents of these elements because they can be related to chlorite which was found in soils of the study area in Cerdeirinha (Table 2). Although, the accumulation of these elements are not limited to clay minerals but also appear in Fe oxides (Kataeva et al. 2004). As well known (e.g., Bigham et al. 2002), oxide-hydroxides have high sorption capacity of trace elements, such as $\mathrm{Ni}, \mathrm{Pb}, \mathrm{Cu}$, and $\mathrm{Zn}$. In accordance with Ni et al. (2009), it is thought that the main adsorbent for $\mathrm{Pb}$ are oxides phases, under conditions of weathering, which can occur in both waste dumps. However, it is known that quartz and feldspars are very weak adsorbent for trace metals, and in turn, the bulk soil fraction is largely composed by these primary minerals. So, trace elements are not concentrated in this fraction, as seen in Figs. 2 and 3 .

In addition, clay fraction showed the highest levels of $\mathrm{Fe}$ for both soils (Fig. 2), which mean that clay-sized minerals such as jarosite and goethite (Table 2) are significant sources of Fe. Also, according with Arocena et al. (1995), these two phases can retain metals such as $\mathrm{Pb}$ and so play a significant role in metal enrichment in fine fraction.

The obtained results suggest a higher capacity of retention by the clay size fraction present at Penedono. Although oxyhydroxides, such as goethite, are known by their high sorption capacity of trace elements, in Penedono, goethite is vestigial. Nevertheless, the mineralogical assemblage composed by kaolinite, illite, smectite, and jarosite seems more effective than the one present at Cerdeirinha. In addition to smectite, illite may also play a significant role in the retention of trace elements, such as Ni, by means of isomorphous substitution of Fe in the octahedral sheet of illite. This may be an explanation for having a higher amount of this element in the $<2-\mu \mathrm{m}$ fraction, especially in Penedono, where there is more quantity of illite.

\section{Conclusion}

Metal and metalloid concentrations in soil reveal that elements, such as $\mathrm{Fe}, \mathrm{Al}$, and $\mathrm{As}$ were present in high quantities in the two waste dumps, being Fe the most abundant element. The XRD study of Penedono shows lower mineralogical variability in the two analyzed fractions, in contrast with Cerdeirinha. These results suggest that the ore deposits have strong influence on the mineralogy of the soil.

The accumulation factor in Penedono presents values higher than 1 for all studied elements. In Cerdeirinha, this accumulation occurs for almost all analyzed elements, with exception of Mn and W. This study indicated that the two waste dumps are heavily polluted with metals and arsenic and that these elements are concentrated in the finer fraction. Thus, it is believed that clay minerals and associated minerals, especially jarosite, may play an important role in sorption of toxic elements at both soils. On the other hand, this enrichment may enhance the environmental risk for pollutant dispersion by wind, water, and animal activity. Hence, the higher degree of contamination by toxic elements, especially arsenic in Penedono, as well as the role of clay minerals, jarosite, and goethite in retaining trace elements has management implications. Such information must be carefully thought in the rehabilitation projects to be planned for both waste dumps.

\section{References}

Acosta JA, Faz A, Arocena JM, Debela F, Martínez-Martínez S (2009) Distribution of metals in soil particle size fractions and its implication to risk assessment of playgrounds in Murcia City (Spain). Geoderma 149:101-109

Acosta JA, Martínez-Martínez S, Arocena J (2011) Accumulations of major and trace elements in particle size fractions of soils on eight different parent materials. Geoderma 161:30-42

Arocena JM, Rutherford PM, Dudas MJ (1995) Heterogeneous distribution of trace elements and fluorine in phosphogypsum by-product. Sci Total Environ 162:149-160

Augustithis S (1995) Atlas of the textural patterns of ore minerals and metallogenic process. Walter de Gryter \& Co, Berlin, 669p 
Bigham JM, Fitzpatrick RW, Schulze DG (2002) Iron oxides. In: Dixon JB, Schulze DG (eds) Soil mineralogy with environmental applications, vol 7, SSSA Book Series. SSSA, Madison, pp 323-367

Cox R, Lowe DR, Cullers RL (1995) The influence of sediment recycling and basement composition on evolution of mud rock chemistry in the southwestern United States. Geochim Cosmochim Acta 59: 2919-2940

Fernández-Caliani JC, Barba C, González I, Galán E (2008) Heavy metal pollution in soils around the abandoned mine sites of the Iberian Pyrite Belt (Southwest Spain). Water Air Soil Pollut. doi:10.1007/ s11270-008-9905-7

Gomes P (2011) Processos de reabilitação natural em escombreiras de minas abandonadas - estudo de casos. MSc thesis, Univ. Porto, Porto, $121 \mathrm{p}$

Hardy M, Cornu S (2006) Location of natural trace elements in silty soils using particle-size fractionation. Geoderma 133:295-308

Huang PM (1989) Feldspars, olivines, pyroxenes, and amphiboles. In: Dixon JB, Weed SB (eds) Minerals in soil environments, vol 1, Soil Sci. Soc. Amer. Book Series. Madison, WI, USA, SSSA, pp 9751050

Kabata-Pendias A, Pendias H (1984) Trace elements in soils and plants. CRC Press, Boca Raton, $315 \mathrm{p}$

Kohut C, Warren C (2002) Chlorites. In: Dixon JB, Schulze DG (eds) Soil mineralogy with environmental applications, vol 7, SSSA Book Series. SSSA Madison, WI, pp 531-553

Kataeva MN, Alexeeva-Popova NV, Drozdova IV, Beljaeva AI (2004) Chemical composition of soils and plant species in the Polar Urals as influenced by rock type. Geoderma 122:257-268

Luo XS, Yo S, Li XD (2011) Distribution, availability, and sources of trace metals in different particle size fractions of urban soils in Hong Kong: implications for assessing the risk to human health. Environ Pollut 159:1317-1326

Malpas J, Duzgoren-Aydin NS, Aydin A (2001) Behavior of chemical elements during weathering of pyroclastic rocks, Hong Kong. Environ Int 26:359-368

Martínez-Martínez S, Faz Á, Acosta JA, Carmona DM, Zornoza R, BüYükkiliç A, Kabas S (2010) Heavy metals distribution in soil particle size fractions from a mining area in the southeast of Spain. 19th World Congress of Soil Science, Soil Solutions for a Changing World. Brisbane, Australia
Moore JN, Brook EJ, Johns C (1989) Grain size partitioning of metals in contaminated, coarse-grained river floodplain sediment: Clark Fork River, Montana, U.S.A. Environ Geol Water Sci 14:107-115

Ni S, Ju Y, Hou Q, Wang S, Liu Q, Wua Y, Xiao L (2009) Enrichment of heavy metal elements and their adsorption on iron oxides during carbonate rock weathering process. Prog Nat Sci 19:1133-1139

Santos Oliveira JM, Farinha Ramos J, Matos JX, Ávila P, Rosa C, Canto Machado MJ, Daniel FS, Martins L, Machado Leite MR (2002) Diagnóstico ambiental das principais áreas mineiras degradadas do país. Boletim de Minas Lisboa 39(2):67-85

Silva LFO, Vallejuelo SF, Martinez-Arkarazo I, Castro K, Oliveira MLS, Sampaio CH, Brum IAS, Leão FB, Taffarel SR, Madariaga JM (2013) Study of environmental pollution and mineralogical characterization of sediment rivers Brazilian coal mining acid drainage. Sci Total Environ 447:169-178

Sposito G (1989) The chemistry of soils. Oxford University Press, New York, $277 \mathrm{p}$

Sarmiento AM, Caraballo MA, Sanchez-Rodas D, Nieto JM, Parviainen A (2012) Dissolved and particulate metals and arsenic species mobility along a stream affected by Acid Mine Drainage in the Iberian Pyrite Belt (SW Spain). Appl Geochem 27:1944-1952

Thornton I (1996) Impacts of mining on the environment: some local, regional and global issues. Appl Geochem 11:355-661

Valente T (2004) Modelos de Caracterização de Impacte Ambiental para Escombreiras Reactivas; Equilíbrio e evolução de resíduos de actividade extractiva. $\mathrm{PhD}$ thesis, Univ. Minho. Braga. $301 \mathrm{p}$

Valente T, Leal Gomes C (2009) Occurrence, properties and pollution potential of environmental minerals in acid mine drainage. Sci Total Environ 407:1135-1152

Valente T, Gomes P, Pamplona J (2011) Natural remediation of mine waste-dumps. Mapping the evolution of vegetation cover in distinctive geochemical and mineralogical environments, Geophysical Research Abstracts, Vol. 13, EGU2011-4230; EGU General Assembly 2011

Valente T, Gomes P, Pamplona J, de la Torre ML (2012) Natural remediation of mine waste-dumps - evolution of the vegetation cover in distinctive geochemical environments. J Geochem Explor 123:152161

Wong CSC, Li XD, Thornton I (2006) Urban environmental geochemistry of trace metals. Environ Pollut 142:1-16
424 


\section{AUTHOR QUERIES}

\section{AUTHOR PLEASE ANSWER ALL QUERIES.}

Q1. Please check if the affiliations are presented correctly.

Q2. "Valente et al. 2009" is cited in text but not given in the reference list. Please provide details in the list.

Q3. "Valente et al. 2014" is cited in text but not given in the reference list. Please provide details in the list.

Q4. The emphasis "bold" in Tables 3 and 4 was removed. Please check. Otherwise, kindly use ital instead and indicate its significance in a table footnote.

Q5. Huang (1989) was not cited anywhere in the text. Please provide a citation. Alternatively, delete the item from the list. 